UDC $613.22+316.722$

DOI: 10.21668/health.risk/2019.4.08.eng

\title{
A COMPARATIVE STUDY OF FOOD CONSUMPTION PATTERNS AMONG CHILDREN YOUNGER THAN THREE IN RUSSIA AND VIETNAM
}

\author{
N.A. Lebedeva-Nesevrya ${ }^{1,2}$, Le Thi Hong $\mathrm{Hao}^{3}$, A.O. Barg ${ }^{1,2}$, Tran Cao Son $^{3}$, \\ Bui Quang Dong ${ }^{3}$, Vu Ngoc Tu ${ }^{3}$, D.V. Suvorov ${ }^{1}$
}

${ }^{1}$ Federal Scientific Center for Medical and Preventive Health Risk Management Technologies, 82 Monastyrskaya Str., Perm, 614045, Russian Federation

${ }^{2}$ Perm State University, 15 Bukireva Str., Perm, 614990, Russian Federation

${ }^{3}$ National Institute for Food Control, 65 Pham Than Duat Str., Hanoi, Vietnam

The publication presents the results of the exposure assessment within the framework of a joint Russian-Vietnamese study aimed at children's health risk assessment associated with the N-nitrosamines contamination in food. People who permanently cared for children aged from six months to three years were questioned in two urbanized areas of Vietnam and Russia - in the cities of Hanoi $(n=481)$ and Perm $(n=183)$. It is shown that the structure of food consumption among children up to three years differs significantly. Children's nutrition in Russia is includes a lot of dry soluble cereals and canned meat/vegetables. The most common product in children's nutrition in Vietnam has no analogues in Russia: it is purchased cereals prepared in specialized stores. Canned foods and dry soluble cereals are also included in the diet of children in Vietnam, but the share of consumers and consumption volumes for them are significantly lower than in Russia. Thus, in the age group of 6-12 months, the share of consumers in Russia is $53 \%$, in Vietnam - 21\%, the median distribution of average daily consumption in Russia is 152 grams, in Vietnam - 28 grams. Taking into account the share of consumers, as well as the volume and frequency of consumption, we determined the priority products for the children's health risk assessment associated with the N-nitrosamines contamination in food. They are canned meat and dry soluble cereals in Russia; grilled meat and sausages; in Vietnam.

Key words: children, food, consumption, risk assessment, Russia, Vietnam, children's nutrition, risk assessment, exposure assessment, questioning.

Introduction. Food-borne diseases have high medical, sanitary and social importance for all modern countries [1]. The WHO Regional Europe Office keeps stressing the importance of achieving higher food products quality and improving nutrition status, especially for vulnerable groups such as elderly people, pregnant women and children [2]. Quality of nutrition provided for children draws special attention of the Regional Bureau programs for East Asia countries, for which nutrition security of infants and young children is one of the top priorities together with immunization and better access to qualified healthcare [3]. Providing adequate nutrition support for children and food-borne diseases prevention are among the top priorities in national policies adopted in different countries,

(C) Lebedeva-Nesevrya N.A., Le Thi Hong Hao, A.O. Barg, Tran Cao Son, Bui Quang Dong, Vu Ngoc Tu, Suvorov D.V., 2019

Natalia A. Lebedeva-Nesevrya - Doctor of Sociological Sciences, Head of the Laboratory for Social Risks Analysis (e-mail: natnes@fcrisk.ru; tel.: +7(342)237-25-47; ORCID: https://orcid.org/0000-0003-3036-3542).

Le Thi Hong Hao - PhD, Managing Director (e-mail: lethihonghao@yahoo.com; tel.: +8 (490) 424-81-67; ORCID: https:// orcid.org/0000-0003-3570-8570).

Anastasiya O. Barg - Candidate of Sociological Sciences, Senior researcher at the Laboratory for Social Risks Analysis (e-mail: an-bg@yandex.ru; tel.: +7(342) 237-25-34; ORCID: https://orcid.org/0000-0003-2901-3932).

Tran Cao Son - Head of the Laboratory for Food Toxicology and Allergens Testing (e-mail: caoson32@gmail.com; sontc@nifc.gov.vn; tel.: +8 (490) 424-81-67; ORCID: https://orcid.org/0000-0002-9779-2715).

Bui Quang Dong - Researcher at the Laboratory for Food Toxicology and Allergens Testing (e-mail: quangdongbui@gmail.com; tel.: +8 (490) 424-81-67; ORCID: https://orcid.org/0000-0003-4807-727X)

Vu Ngoc Tu - Researcher at the Laboratory for Food Toxicology and Allergens Testing (e-mail: vungoctu1986@gmail.com; tel.: +8 (490) 424-81-67; ORCID: https://orcid.org/0000-0003-4262-4471).

Dmitrii V. Suvorov - Junior researcher at the health Risks Analysis Department, post-graduate student (e-mail: suvorov@fcrisk.ru; tel.: 8 (342) 238-33-37; ORCID: https://orcid.org/0000-0002-3594-2650). 
for example, of Food quality improvement strategy in Russian Federation till $2030^{1}$ and National strategy of Vietnam in nutrition sector in 2011-2020 2 .

One of the main problems related to nutrition for children is food contamination [4]. Consequently, there is a pressing issue whether it is possible to produce contamination-free organic food for children, taking into account the intensive pollution of the environment (soil, water, and air) [5]. Among foreign chemical substances, found in food, nitrates are especially hazardous [6], as they deoxidize to nitrites in human body, thus making a base for carcinogenic N-nitrosamines occurrence [7]. Russian researchers have fixed nitrate contamination of drinking water $[8,9]$ and others nutrition products (vegetables $[10,11]$, greenery [12], and fruit [13]). Within joint studies of Russian and Vietnamese researchers $\mathrm{N}$-nitrosamines were detected in canned meat for babies [14] and in baby cereals with and without milk [15].

Assessment of health risks caused by food contamination with hazardous chemical substances, which include $\mathrm{N}$-nitrosamines, allows not only to define the quantitative measurement of food contamination but also to characterize the different groups of products consumed by the population.

The purpose of the study was to comparatively examine actual food consumption by children younger than 3 in Russia and Vietnam in order to assess health risks associated with influence exerted by contaminated food on children's health.

Data and methods. The object of the study was child population living on urbanized territories in Russia and Vietnam. In Vietnam the study was organized in Hanoi (the capital city, huge financial and industrial centre with its population being equal to 7.7 million people), In Russia it was organized in Perm (huge industrial centre with its population being equal to 1 million people). Necessary data were collected via questioning conducted among people who took care of children aged from 6 months to 3 years. At the first stage (summer - autumn 2018) the questioning was organized in Perm and analysis procedures and tools were tested. At the second stage (winter - spring 2019). after the procedures and tools had been corrected and adapted, the questioning was organized in Hanoi.

In Perm the questioning was organized in six random polyclinics for children in six districts of the city (except the Lenin district, due to low population number living there and specific low-rise housing). In these polyclinics random pediatricians gave out questionnaires to adult visitors with children younger than 3 . Total sampling included 183 people (children aged from 6 months to 3 years accounted for $35 \%$; children aged 13-24 months, 36\%; children aged 25-36 months, $29 \%$; $49 \%$ children were boys, and $51 \%$, girls).

In Hanoi, the questioning was organized in child health and nutrition centers in two districts of the city (Dong Da and Bac Tu Liem) and two counties (Dan Phuong and Thanh Tri), which were parts of Hanoi in order to provide a representative population sampling according to social and economic characteristics. Total sampling included 481 people (children aged from 6 months to 3 years accounted for $30 \%$; children aged 13-24 months, $46 \%$; children aged 25-36 months, $24 \%$; $51 \%$ children were boys, and $49 \%$, girls).

Research tools included two general sets of questions: a) one concerning eating meat, meat and vegetable, vegetable canned baby food and baby cereals with milk (food products with detected N-nitrosamines contamination $[14,15]), b)$ demographical questions (sex and age of a child, social and economic status and members of the family). Questionnaires in

\footnotetext{
${ }^{1}$ Food quality improvement strategy in Russian Federation till 2030 year. Approved by the Order of Russian Federation Government dated of 29 June 2016 No. 1364-r. Available at: http://www.garant.ru/products/ipo/prime/doc/71335844/ (01.12.2019).

${ }^{2}$ Food quality improvement strategy in Russian Federation till 2030 year. Approved by the Order of Russian Federation Government dated of 29 June 2016 No. 1364-r. Available at: http://www.garant.ru/products/ipo/prime/doc/71335844/ (01.12.2019).
} 
Vietnam included questions aimed at estimating consumption of products that were typical for the country. Those products were cooked cereals (fresh cereals), which could be bought in specific retail outlets, grilled sausages and meat. The reason for these products being included into the questionnaire was a hypothesis that they might include N-nitrosamines.

Questioning results were processed electronically with SPSS Statistics 22 software package (descriptive statistics, central tendencies measures definition, and correlation analysis).

Results. The structure of food consumption, which is of interest as regards assessing risks associated with the impacts exerted by $\mathrm{N}$-nitrosamines on children's health in Russia and Vietnam, has significant differences already in the youngest age group. Among Russian children aged from 6 to 12 months, $61 \%$ have experience in consuming canned meat and vegetable products, while in Vietnam only $36 \%$ consumers in this age group eat such products. At the same time, fresh cooked cereals (both cereals without admixtures or ones with the beef, pork, turkey, fish, crab meat and shrimp) are highly popular in Vietnam; from $90 \%$ to $98 \%$ of Vietnamese children in the examined age groups and $95 \%$ in the overall sampling have eaten this type of product. Fresh cereals cooked in retail outlets have no analogues in Russia (the closest type of product is cereals that are cooked at home or at catering companies, but in Russia meat and poultry are usually added only to buckwheat cereal, and fish and seafood are not added at all).
The average daily consumption of fresh cooked cereals in Vietnam is quite large - the median of distribution among children aged 6-12 months was 92.8 grams; among those aged 13-24 months, 200 grams; among children aged 25-36 months, 171.4 grams. The consumption volume of this product among boys aged from 6 to 12 months was significantly higher than among girls of the same age (Cramer's $\mathrm{V}=0.211$ at $\mathrm{p} 00.05$ ); the proportion of consumers with an average daily volume being equal to 300 grams or more among boys aged 6-12 months was by $10 \%$ higher than among girls of the same age. The most popular cereals were beef (from $55 \%$ to $78 \%$ consumers in the examined age subgroups) and turkey (from $58 \%$ to $80 \%$ consumers).

Differences in food consumption patterns in Russia and Vietnam were also observed concerning dry instant cereals as consumers of this product among Russians in the age group from 6 to 12 months accounted for $53 \%$, and among Vietnamese only $21 \%$ (Table 1).

As Table 1 shows, the proportion of children consuming canned industrially manufactured products is gradually growing in Vietnam (up to $67 \%$ among children aged 25-36 months), while in Russia it remains almost permanent among children aged 6-24 months, and then increases to $75.5 \%$ for the oldest children aged 25-36 months. At the same time, a significant part of canned food consumed in Russia is canned meat (in the age group of 6-12 months, $88 \%$ of consumers preferred onecomponent canned meat), while in Vietnam

Table 1

A share of consumers eating various products in Russia and Vietnam (as a percentage of all respondents in group)

\begin{tabular}{|l|c|c|c|c|c|c|}
\hline \multirow{2}{*}{ Food product type } & \multicolumn{2}{c|}{$6-12$ months } & \multicolumn{2}{c|}{$13-24$ months } & \multicolumn{2}{c|}{$25-36$ months } \\
\cline { 2 - 7 } & Russia & Vietnam & Russia & Vietnam & Russia & Vietnam \\
\hline Grilled meat & No data & 10.5 & No data & 52.9 & No data & 74.1 \\
\hline Sausages & No data & 11.9 & No data & 61.5 & No data & 87.9 \\
\hline Canned food & 60.7 & 35.7 & 54.1 & 57.5 & 75.5 & 67.2 \\
\hline Dry instant cereals & 53.0 & 21.0 & 40.0 & 44.8 & 26.0 & 45.7 \\
\hline Fresh cereals cooked in retail outlets & No data & 90.9 & No data & 95.0 & No data & 98.3 \\
\hline
\end{tabular}


The average daily consumption of various food products in Russia and Vietnam (distribution median)

\begin{tabular}{|l|c|c|c|c|c|c|}
\hline \multirow{2}{*}{\multicolumn{1}{|c|}{ Food product type }} & \multicolumn{2}{c|}{$6-12$ months } & \multicolumn{2}{c|}{$13-24$ months } & \multicolumn{2}{c|}{$25-36$ months } \\
\cline { 2 - 7 } & Russia & Vietnam & Russia & Vietnam & Russia & Vietnam \\
\hline Grilled meat & No data & 21.4 & No data & 23.6 & No data & 35.7 \\
\hline Sausages & No data & 28.5 & No data & 17.1 & No data & 28.6 \\
\hline Canned food & 50.1 & 14.2 & 104 & 21.4 & 58.0 & 15.7 \\
\hline Dry instant cereals & 152.4 & 28.5 & 200.0 & 50.0 & 280.0 & 78.5 \\
\hline Freshly cooked cereals in store production & No data & 92.8 & No data & 200.0 & No data & 171.4 \\
\hline
\end{tabular}

this type of canned food is absolutely not popular as all consumers of canned food consumed meat and vegetable or multi- and onecomponent vegetable canned food.

Children in Russia eat less dry instant cereals with aging and the share of consumers is gradually reducing to $26 \%$ in the 25-36 months subgroup, and in Vietnam, this share rises to $46 \%$ for the elder group, while it remains permanent in the previous two subgroups.

The average daily consumption of canned food and instant cereals in the studied samples also varies significantly. Thus, in the 25-36 months subgroup, where the share of canned food consumers is the largest in both countries, the distribution median of the average daily consumption of canned food was 58 grams in Russia and only 15.7 grams in Vietnam. The median distribution of the average daily consumption of dry instant cereals in the middle age group of 13-24 months was 200 grams in Russia and only 50 grams in Vietnam (Table 2).

Significant differences are observed in the average daily consumption of dry instant cereals by 13-24 months old boys and girls in Vietnam (Cramer's $\mathrm{V}=0.258$ at $\mathrm{p}<0.05$ ).

Starting from 13 months sausages and grilled meat are actively included into nutrition provided for Vietnamese children. So, $61.5 \%$ of $13-24$ months old children and $88 \%$ of $25-36$ months old children have experience in eating sausages, the share of grilled meat consumers in these groups amounts to $53 \%$ and $74 \%$, respectively. The average daily consumption of grilled meat increases with aging: the median value among children aged
6-12 months was 21.4 grams; $13-24$ months, 23.6 grams; $25-36$ months, 35.7 grams. The average daily consumption of sausages was the same in the youngest and oldest age groups (distribution medians were 28.5 and 28.6 grams, respectively), and it was significantly lower in the 13-24 months group (17.1 grams).

Discussion. The structure of nutrition provided for children younger than three years in Russia and Vietnam is different due to economic, historical and cultural reasons. The low popularity of canned baby products in Vietnam is due to a rather small number of local producers (two brands against four in Russia), the high cost of imported products in relation to the average per capita income in the country (it results in its low physical availability, poor assortment offered by retail outlets and supermarkets), as well as due to preference for more high-calorie meat products. As a 2013 study in the Dong Da area (central Hanoi, also included in the survey sampling) showed, parents in Vietnam often implement «intensive feeding practices» for their preschool children, wanting their children to eat more high-calorie foods. This behavior pattern may be associated with historical experience of surviving starvation during wars, when children were the most vulnerable group [16].

The intensive inclusion of the products that are not recommended for preschool children (sausages, grilled products, or sweets) into children's ration has been noted in several other studies in Vietnam. Thus, a survey conducted in five urban areas of Central and South Vietnam revealed a high level of consumption sweets by children aged from two to 
five years [17]. However, misbalance in children's ration among children aged from one to three years is also typical for Russia. According to the data provided by the Russian Pediatricians Union, $56 \%$ children began to receive confectionery products and "notfor children" products (snacks, mayonnaise, or semi-finished products) when they were about two years old [18]. The data of the RAMS Institute of Nutrition indicate that there are sausages in ration offered to $23.4 \%$ of Russian children aged 1-2 years [19].

The tendency among Russian parents to use ready meals for children (canned food, dry instant cereal) detected during the study is associated with a desire to reduce an amount of time spent on cooking. A similar behavior is observed when analyzing the results obtained via examining the Vietnamese sampling as fresh cooked cereals produced by retail outlets, which are popular in Vietnam, are an alternative option of «fast food» and similarly help saving time spent on cooking.

Conclusions. The study allowed us to draw a number of conclusions regarding the characteristics of food consumption by children younger than three in Russia and Vietnam:

1. Children in Russia and in Vietnam eat canned baby food. Children in Russia start eating meat and vegetable canned food earlier. In two of the three age children subgroups, the proportion of canned baby food consumers in Russia is higher than in Vietnam. The difference is especially apparent in the age group of 6-12 months: in Russia $61 \%$ children in this age group consume this type of products, and in Vietnam their share is almost two times lower (36\%);

2. The average daily consumption of canned baby food in Russia is higher than in Vietnam. While in all age groups in Vietnam children receive no more than 30 grams of canned food per day, in Russia the average daily consumption is 88 grams (arithmetic average for the sampling as a whole);

3. Dry instant cereals are a typical choice for the first supplemental feeding for 6 to 12 months old children in Russia. Over half $(53 \%)$ of children in the youngest age group received this food product. In Vietnam, the proportion of consumers who eat dry instant cereals amounted to months $21 \%$ among children aged 6-12. With aging, the share of product consumers in Russia decreases (to $26 \%$ in the group of children 25-36 months old). In Vietnam, in groups of 12-24 months and 25-36 months, the proportion of children who ate dry instant cereals is approximately $44-45 \%$;

4. Average daily consumption of instant cereals by children in Russia is higher than in Vietnam in all age groups. The differences are especially apparent in the youngest group (6-12 months), 191 grams in Russia against 42 grams in Vietnam (arithmetic mean distributions). In general, instant cereals are the main (daily) food product for children in Russia, while in Vietnam this type of product is not included in children's ration, the frequency of its consumption is low;

5. Grilled sausages and meat (products potentially contaminated with N-nitrosamines) are actively introduced into children's ration in Vietnam from the age of 12 months. In a 12-24 months subgroup, sausages are consumed by $61 \%$ children, and grilled meat, by $53 \%$. In the age group of 25-36 months, the proportion of children who have eaten these types of products increases to $88 \%$ and $74 \%$, respectively;

6 . The priority products for research in the framework of evaluation the risk associated with the impact of chemical contamination of food products with $\mathrm{N}$-nitrosamines on the health of children under three years are: meat and vegetable canned food and dry instant cereals in Russia, grilled meat and sausages in Vietnam;

7. When performing studies to evaluate health risks caused by chemical contamination of food products, including food for young children, estimation of their actual consumption is a key condition for reducing exposure estimation uncertainty.

Financing. The study did not have any financial support.

Conflict of interests. Authors declare there is no any conflict of interests. 


\section{References}

1. Global'naya strategiya VOZ v oblasti bezopasnosti pishchevykh produktov [WHO Global strategy for food safety]. World Health Organization, 2002, 34 p. Available at: https://apps.who.int/ iris/handle/10665/85375 (01.12.2019) (in Russian).

2. Pitanie. Politika [Nutrition. Policy]. Regional office for Europe. World Health Organization. Available at: http://www.euro.who.int/ru/health-topics/disease-prevention/nutrition/policy (01.12.2019) (in Russian).

3. Infant and young child feeding in South-East Asia Region. WHO South-East Asia. Available at: https://www.who.int/southeastasia/health-topics/infant-and-young-child-feeding (01.12.2019).

4. Pivovarov Yu.P., Milushkina O.Yu., Tikhonova Y.L., Aksenova O.I., Kalinovskaya M.V. Chemical pollution of baby food products in the Russian. Gigiena i sanitariya, 2016, vol. 95, no. 8, pp. 707-711 (in Russian).

5. Bel'mer S.V., Gasilina T.V. Some aspects of hygienic sagety children's foods. Voprosy detskoi dietologii, 2008, vol. 6, no. 2, pp. 27-31 (in Russian).

6. Setko A.G., Mryasova Zh.K., Tyurin A.V. Risk of health disorders in children caused by consumption of contaminated food products. Health Risk Analysis, 2018, no. 4, pp. 89-95 (in Russian). DOI: $10.21668 /$ health.risk/2018.4.10.eng

7. Zaitseva N.V., Ulanova T.S., Nurislamova T.V., Terent'ev G.I., Popova N.A., Mal'tseva O.A. Determination of N-nitrosodiphenylamine in meat canned food for children by the method of chromato-mass-spectrometry. Voprosy pitaniya, 2017, vol. 85, no. 5, pp. 56-62 (in Russian).

8. Luzhetskiy K.P. Methodical approaches to managing risks for endocrine diseases evolvement in children related to impacts of environmental factors occurring on areas aimed for development. Health Risk Analysis, 2017, no. 2, pp. 47-56 (in Russian). DOI: 10.21668/health.risk/2017.2.05.eng

9. Kleyn S.V., Vekovshinina S.A., Sboev A.S. Priority risk factors of drinking water and the related with it economical loss. Gigiena i sanitariya, 2016, vol. 95, no. 1, pp. 10-14 (in Russian).

10. Istomin A.V., Eliseev Yu.Yu., Eliseeva Yu.V. Conditionality of risks to health of the children's population chemical contamination of foodstuff in the region. Zdorov'e naseleniya $i$ sreda obitaniya, 2014, vol. 251, no. 2, pp. 18-21 (in Russian).

11. Kozlova A.B., Stokoz S.V. Estimation of the nitrate availability level in vegetables coming to the Blagoveshchensk town market. Vestnik KrasGAU, 2009, vol. 39, no. 12, pp. 95-100 (in Russian).

12. Butakov V.V., Tropnikova V.V. Analiz soderzhaniya nitratov v ovoshchakh, fruktakh i zeleni torgovoi seti Novosibirska [Analysis of nitrates contents in vegetables, fruit, and potherbs sold in retail outlets in Novosibirsk]. In Situ, 2016, no. 3, pp. 20-24 (in Russian).

13. Zhidkin V., Semushev A. Food contamination by nitrates, pesticides and heavy metals. Predprinimatel'stvo, 2014, no. 5, pp. 190-198 (in Russian).

14. Zaitseva N.V., Tran Cao Son, Bui Cao Tien, Ulanova T.S., Nurislamova T.V., Maltseva O.A. Comparative assessment of N-nitrosamines' contamination of baby's canned meat with vegetables and cereals by various methods in Russia and Vietnam. Voprosy pitaniya, 2019, vol. 88, no. 5, pp. 93-102 (in Russian).

15. Zaitseva N.V., Ulanova T.S., Nurislamova T.V., Terent'ev G.I., Ershova K.S., Mal'tseva O.A. Control of highly toxic N-nitrosamines (N-nitrosodimethylamine and $\mathrm{N}$-nitrosodiethylamine) content in baby's cereals. Voprosy pitaniya, 2016, vol. 85, no. 3, pp. 82-90 (in Russian).

16. Do L.M., Eriksson B., Tran T.K., Petzold M., Ascher H. Feeding of preschool children in Vietnam: a study of parents' practices and associated factors. BMC Nutrition, 2015, no. 1, pp. 16. DOI:10.1186/s40795-015-0011-0

17. Huang D., Sokal-Gutierrez K., Chung K., Lin W., Khanh L.N., Chung R., Hoang H.T., Ivey S.L. Maternal and Child Nutrition and Oral Health in Urban Vietnam. International Journal of Environmental Researches and Public Health, 2019, vol. 16, no. 14, pp. 2579. DOI: 10.3390/ijerph16142579

18. Natsional'naya programma optimizatsii pitaniya detei v vozraste ot 1 goda do 3 let v Rossiiskoi Federatsii. Press-reliz [National program for optimizing nutrition provided for children aged 
1-3 in the Russian Federation. Press release]. Pediatricheskaya farmakologiya, vol. 12, no. 6, pp. 707-708 (in Russian).

19. Baturin A.K., Keshabyants E.E., Safronova A.M., Netrebenko O.K. Programmirovanie pitaniem: pitanie detei starshe goda [Programmed by nutrition: nutrition for children after 1 year of age]. Pediatriya. Zhurnalim. G.N. Speranskogo, 2013, vol. 92, no. 2, pp. 91-99 (in Russian).

20. Borovik E., Guseva I.M., Semenova N.N., Zvonkova N.G., Zakharova I.N., Surzhik A.V., Stepanova T.N., Bushueva T.V. [et al.]. Pediatrician and parent opinion on nutrition in infants under 3 years: results of pilot survey conducted in central federal district of the Russian Federation. Voprosy sovremennoi pediatrii, 2016, vol. 15, no. 4, pp. 358-363 (in Russian).

Lebedeva-Nesevrya N.A., Le Thi Hong Hao, Barg A.O., Tran Cao Son, Bui Quang Dong, Vu Ngoc Tu, Suvorov D.V. A comparative study of food consumption patterns among children younger than three in Russia and Vietnam. Health Risk Analysis, 2019, no. 4, pp. 77-83. DOI: 10.21668/health.risk/2019.4.08.eng

Received: 20.11 .2019

Accepted: 19.12 .2019

Published: 30.12.2019 